\title{
The Ameliorative Effect of $\beta$-sitosterol on DNCB-induced Atopic Dermatitis in Mice
}

\author{
Su-Jin Kim \\ Department of Biotechnology and Convergence, College of Herbal Bioindustry, \\ Daegu Haany University, Kyungsan 38610, Korea
}

\begin{abstract}
$\beta$-sitosterol, one of phytosterols, exhibited numerous pharmacological effect including anti-inflammatory, anti-cancer and immune-modulating properties. This study attempted to determine the pharmacological effects of $\beta$-sitosterol on atopic dermatitis (AD). We investigated to ascertain the pharmacological effects of $\beta$-sitosterol on 2, 4-dinitrochlrobenzene (DNCB)-induced $\mathrm{AD}$ symptom and histamine-induced scratching behaviors in mice. Additionally, we evaluated the effects of $\beta$-sitosterol on the interleukin (IL)-6 levels in HaCaT cells and skin tissue of AD. The findings of this study demonstrated that $\beta$-sitosterol reduced $\mathrm{AD}$ clinical symptoms such as eczematous, erythema and dryness and serum histamine and IgE levels in DNCB-induced AD model and histamine-induced scratching behaviors in mice. Additionally, $\beta$-sitosterol inhibited the IL-6 expression in AD-like skin lesion and HaCaT cells. Collectively, these findings provide that $\beta$-sitosterol could be a therapeutic agent for skin inflammation including AD.
\end{abstract}

Key Words: $\beta$-sitosterol; Atopic dermatitis; Interleukin-6; HaCaT cells

\section{INTRODUCTION}

Atopic dermatitis $(\mathrm{AD})$ is a common skin disease characterized by a chronic and relapsing inflammatory dermatitis (Buske-Kirschbaum et al., 2001). AD is known to be the result of an immune system dysregulation, ultimately resulting in allergic inflammation (Gold and Kemp, 2005). In the past decades, $\mathrm{AD}$ research has enormously increased due to the rapid increase of $\mathrm{AD}$ related skin inflammation around the world. Generally, most therapy for $\mathrm{AD}$ is corticosteroids (Berke et al., 2012) but these long-term treatments cause serious side effects such as immunosuppression, and epidermal barrier dysfunction (Shiohara et al., 2004). Con- sequently, there is a need for anti-atopic agents that cause fewer side effects.

Keratinocytes, which are the main epidermal cells, are considered to play a critical role in $\mathrm{AD}$ (Eichenfield et al., 2012). Keratinocyte produces inflammatory cytokines and chemokines by various stimulations (Vestergaard et al., 2000). These mediators contribute to the infiltration of inflammatory cells to sites of inflammation in the skin. Recent studies have reported that inflammatory cytokines are involved in the initiation of $\mathrm{AD}$. It was reported that cytokines were expressed at high levels in skin lesion of $\mathrm{AD}$ patients and it suggests that inflammatory cytokine plays an integral role in the pathogenesis of these conditions (Homey et al., 2006). Hence, there is a strong interest in the development of agents

\footnotetext{
* Received: September 11, 2017 / Revised: November 28, 2017 / Accepted: December 7, 2017

${ }^{\dagger}$ Corresponding author: Su-Jin Kim. Department of Biotechnology and Convergence, College of Herbal Bioindustry, Daegu Haany University, Yugok-dong, Kyungsan 38610, Korea.

Tel: +82-53-819-1389, Fax:+82-53-819-1272, e-mail: ksj1009@dhu.ac.kr

(C) The Korean Society for Biomedical Laboratory Sciences. All rights reserved.

(C) This is an Open Access article distributed under the terms of the Creative Commons Attribution Non-Commercial License (http://creativecommons.org/licenses/by-nc/3.0/) which permits unrestricted non-commercial use, distribution, and reproduction in any medium, provided the original work is properly cited.
} 


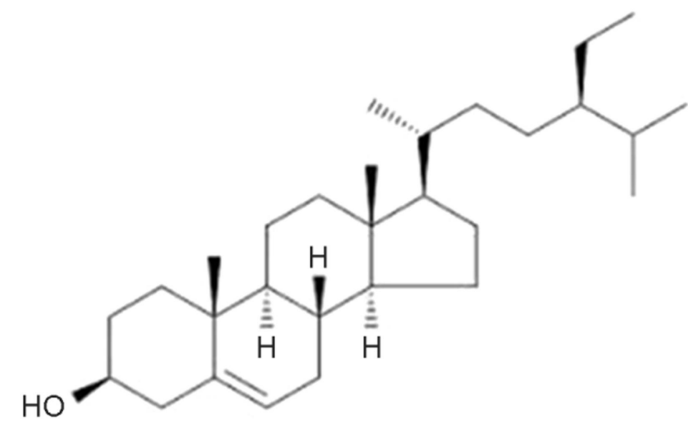

Fig. 1. Chemical structure of $\beta$-sitosterol.

that can block the generation or action of inflammatory cytokines.

As natural products are safe and devoid of toxicity, it has been the subject of increased interest for the development of new drugs against a wide range of diseases such as cancers and inflammatory diseases. $\beta$-sitosterol is a most common phytosterols and a chemical structurally related to cholesterol (Fig. 1). It presents in numerous plants such as rice, wheat and corn and exhibits anti-inflammatory, angiogenic and immune-modulating properties (Heitzman et al., 2005; Ling and Jones, 1995). In the present study, we elucidate whether $\beta$-sitosterol modulates the $\mathrm{AD}$ in mice. We investigated the pharmacological effects of $\beta$-sitosterol on 2 , 4-dinitrochlrobenzene (DNCB)-induced $\mathrm{AD}$ symptom and histamine-induced scratching behaviors in mice. Additionally, we evaluated the effects of $\beta$-sitosterol on the Interleukin (IL)-6 levels in AD-like skin lesion and HaCaT cells.

\section{MATERIALS AND METHODS}

\section{Reagents}

$\beta$-sitosterol, Compound 48/80, histamine, terfenadine, avidin peroxidase (AP) and 1-chloro-2,4-dinitrochlorobenzene (DNCB) were purchased from Sigma Chemical Co. (St. Louis, MO, USA). Roswell Park Memorial Institute (RPMI) 1640 was purchased from Gibco BRL (Grand Island, NY, USA). Fetal bovine serum (FBS) was purchased from Thermo Fisher Scientific Inc. (Somerset, NJ, USA). Anti-mouse IL-6/ IgE, recombinant IL-6/IgE and biotinylated IL-6/IgE were purchased from BD Pharmingen (San Diego, CA, USA).

\section{Animals}

Male ICR mice ( 5 weeks, $18 \sim 20 \mathrm{~g}$ ) and BALB/c mice (5 weeks, 19 20 g) were purchased from the Daehan biolink Co., Ltd. (Chungbuk, Korea). Animals were housed 6 heads per cage, allowed spontaneous take in food and water Animals were kept under a 12-h light/dark cycle (light on 08:00-20:00) at room temperature $\left(23 \pm 2{ }^{\circ} \mathrm{C}\right)$ and humidity $(55 \pm 10 \%)$. The research was conducted in accordance with the internationally accepted principles for laboratory animal use and care as found in Daegu Haany university guidelines.

\section{Induction of AD-like skin Lesions and $\beta$-sitosterol treat- ment}

Induction of $\mathrm{AD}$-like skin lesions procedure is described in Fig. 2. DNCB (Sigma-Aldrich, St. Louis, MO, USA) was dissolved in vehicle (3:1 acetone olive oil) and used as a sensitizer for inducing AD-like skin lesions in mice (Yoon et al., 2015). Backs of mice were shaved with a clipper and depilatory cream, washed with sterilized PBS and gauzed a day before sensitization. Mice were divided into 5 groups with 6 mice per group: vehicle, DNCB, and DNCB plus treatment of $\beta$-sitosterol $(0.2 \mathrm{mg} / \mathrm{kg})$ or $\beta$-sitosterol $(2 \mathrm{mg} /$ $\mathrm{kg}$ ) or terfenadine $(10 \mathrm{mg} / \mathrm{kg})$. Exposed skin was treated with vehicle alone or with $200 \mu \mathrm{L}$ of a $1 \%$ DNCB. On day 4 after sensitization, the back skin was challenged with $200 \mu \mathrm{L}$ of a $0.2 \%$ DNCB solution three times per week. This procedure was repeated for 4 weeks and $\beta$-sitosterol was orally administrated 2 weeks before the end of the experiment.

\section{Evaluation of skin dermatitis severity}

The severity of dermatitis was assessed macroscopically according to the Eczema Area and Severity Index (EASI) scoring system: 0, no symptoms; 1, mild symptoms; 2, moderate symptoms; and 3, severe symptoms. The severity of dermatitis was evaluated by the naked eye of three blind examiners. The sum of the individual scores was defined as the dermatitis score for erythema/hemorrhage, edema, excoriation/erosion and scaling/dryness (Hanifin et al., 2001). 


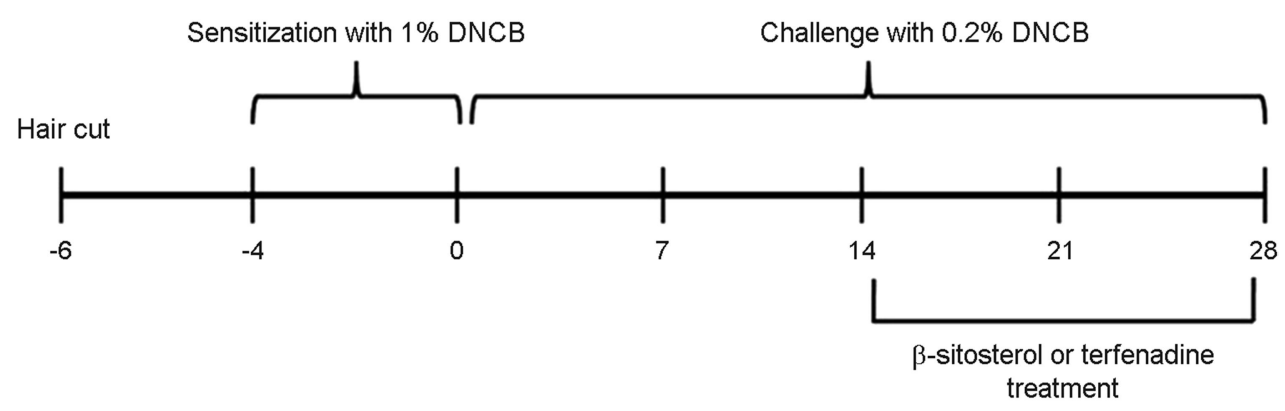

Fig. 2. Experimental protocol for induction of $A D$ and $\beta$-sitosterol treatment.

\section{Scratching behavioral experiment}

Before the experiment, the ICR mice ( $\mathrm{n}=6 /$ each group) were put into acrylic cages $(22 \times 22 \times 24 \mathrm{~cm})$ for about 30 $\min$ for acclimation. The behavioral experiments were performed according to the method of Sugimoto et al. (2006). The rostral part of the skin on the back of mice was clipped, and histamine $(100 \mu \mathrm{g} / \mathrm{kg})$ for each mouse was intradermally injected. The scratching agents were dissolved in tween 80 and then used. Control mice received a Tween 80 injection in place of the scratching agent. Immediately after the intradermal injection, the mice (one animal/cage) were put back into the same cage for the observation of scratching. Scratching of the injected site by the hind paws was counted and compared with that of the other sites, such as the ears. Each mouse was used for only one experiment. The mice generally showed several scratches for $1 \mathrm{~s}$, and a series of these behaviors was counted as one incident of scratching for $30 \mathrm{~min}$. $\beta$-sitosterol $(0.2$ and $2 \mathrm{mg} / \mathrm{kg})$ and terfenadine $(10 \mathrm{mg} / \mathrm{kg}$ ) was orally administered $1 \mathrm{~h}$ before the scratching agents.

\section{Cell culture}

Human immortalized keratinocytes (HaCaT cells) were cultured in RPMI1640 (100 unit $/ \mathrm{ml}$ penicillin, $100 \mu \mathrm{g} / \mathrm{ml}$, streptomycin, and $10 \%$ heat-inactivated FBS) at $37^{\circ} \mathrm{C}, 5 \%$ $\mathrm{CO}_{2}$ and $95 \%$ humidity.

\section{IL-6 and IgE assay}

Skin tissue were homogenized in lysis buffer and centrifuged at 12,000 rpm for $10 \mathrm{~min}$. The supernatants were used as the cytokine containing extract and protein concentrations were determined using BCA protein assay reagent (Sigma) Blood was collected and serum was separated by centrifugation at $4,000 \times \mathrm{g}$ for $20 \mathrm{~min}$ at $4{ }^{\circ} \mathrm{C}$. Levels of IL-6 in skin tissue and IgE in serum were measured using an enzymelinked immunosorbent assay (ELISA), as previously described (Kim et al., 2010). Briefly, 96-well plates were coated with anti-mouse monoclonal antibodies and incubated overnight at $4{ }^{\circ} \mathrm{C}$. After additional washes, sample or an IL-6 or IgE standard were added and incubated at room temperature for $2 \mathrm{~h}$. Plates were then washed and biotinylated anti-mouse antibody was added and incubated at room temperature for $2 \mathrm{~h}$. After washing plates, avidin-peroxidase was added, and plates were incubated for $30 \mathrm{~min}$ at $37^{\circ} \mathrm{C}$. The plates were then rewashed and ABTS substrate was added. Color development was measured at $405 \mathrm{~nm}$ using an automated microplate ELISA reader.

\section{Histamine assay}

Concentrations of histamine in serum isolated from sacrificed mice were measured with a specific ELISA kit according to the manufacturer's instructions (Abnova, CA, USA).

\section{Statistical analysis}

The experiments were shown a summary of the data from at least-three experiments and presented as the mean \pm S.D. Statistical evaluation of the results was performed by independent $t$-test. A value of $P<0.05$ was considered statistically significant. 
A

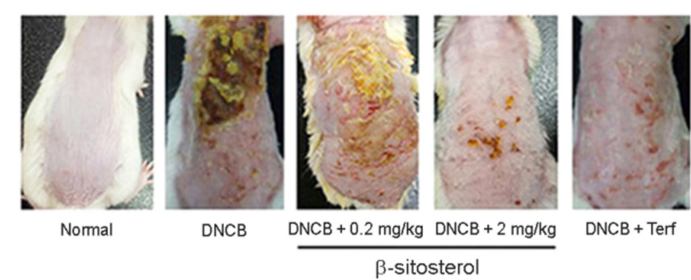

B

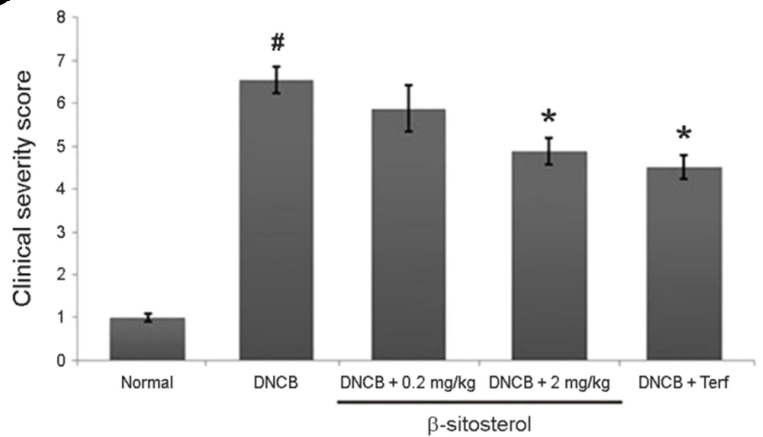

Fig. 3. Effect of $\beta$-sitosterol on DNCB-induced AD in mice. (A) The mice were sensitized with $0.1 \%$ DNCB in acetone-olive oil $(3: 1)$ or vehicle applied to the dorsal skin twice each week for a total period of 5 weeks. After 3 weeks, $\beta$-sitosterol $(0.2$ and $2 \mathrm{mg} / \mathrm{kg}$ ) or Terfenadine $(10 \mathrm{mg} / \mathrm{kg})$ was orally administered 2 weeks prior to the end of the experiment. (B) The score of skin severity is represented. The data represents the mean \pm S.D. of three independent experiments ( $\# P<0.05$ vs. control group, $* P<0.05$ vs. DNCBtreated group).

\section{RESULTS}

\section{Effect of $\boldsymbol{\beta}$-sitosterol on DNCB-induced atopic dermatitis in mice}

In order to evaluate the regulatory effects of $\beta$-sitosterol on $\mathrm{AD}$ in vivo model, $\mathrm{DNCB}$ was administered to $\mathrm{BALB} / \mathrm{c}$ mice. As shown in Fig. $3 \mathrm{~A}$, when mice were treated for 2 weeks with $\beta$-sitosterol, DNCB-induced the AD symptoms such as eczematous, erythema and dryness were recovered to a significant extent. We observed that the skin severity scores in the $\beta$-sitosterol group and the terfenadine group were significantly lowered compared to DNCB-treated group $(P<0.05)$. Terfenadine was used as a positive control in this study (Fig. 3B).

\section{Effect of $\beta$-sitosterol on histamine and IgE serum levels in $\mathrm{AD}$ mice}

An important feature of $\mathrm{AD}$ is the pathological secretion of histamine and IgE (Saeki et al., 2009). Thus, we evaluated

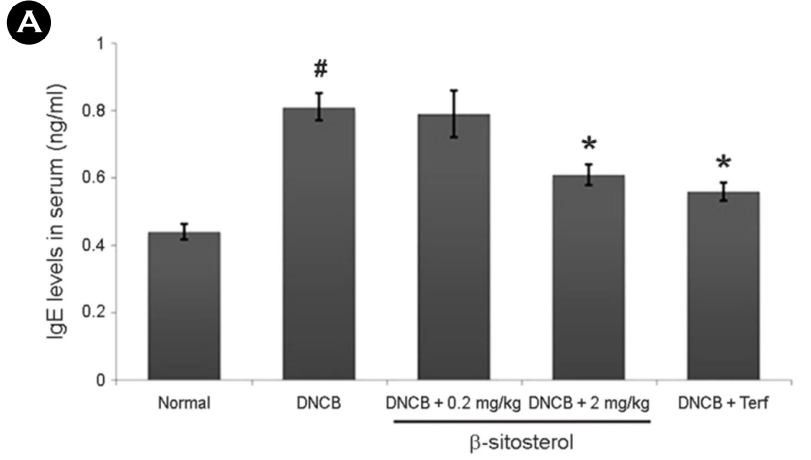

B

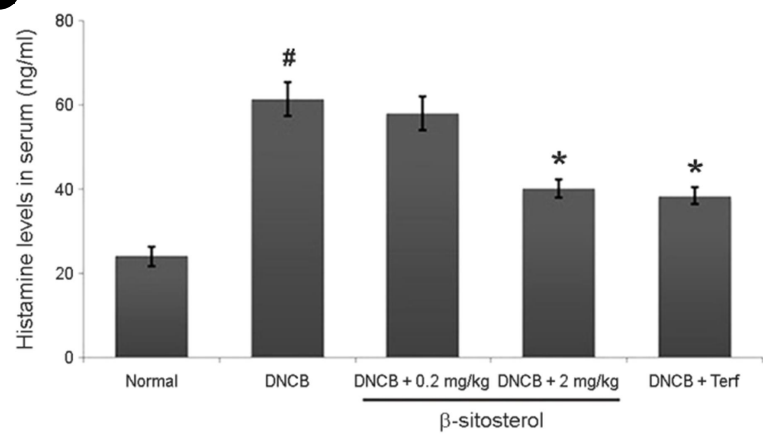

Fig. 4. Effect of $\beta$-sitosterol on the histamine and $\operatorname{IgE}$ serum levels (A and B) Blood samples in DNCB-induced AD mice were collected and then levels of serum histamine and $\operatorname{IgE}$ were measured using ELISA method. The data represents the mean \pm S.D. of three in dependent experiments ( $\# P<0.05$ vs. control group, $* P<0.05$ vs. DNCB-treated group).

the effect of $\beta$-sitosterol on histamine and IgE levels in serum using ELISA. As shown in Fig. 4A and B, the application of DNCB to mice resulted in an increased release of histamine and $\operatorname{IgE}$ in the serum. In contrast, the $\beta$-sitosterol-treated group showed a considerable reduction in histamine and IgE levels in the serum. The inhibition rate of histamine and $\operatorname{IgE}$ by $\beta$-sitosterol $(2 \mathrm{mg} / \mathrm{kg})$ was approximately $35.2 \%$ and $29.4 \%$, respectively $(P<0.05)$.

\section{Effect of $\beta$-sitosterol on scratching behaviors in mice}

The anti-pruritic effect of $\beta$-sitosterol was investigated on the histamine-induced scratching behavior in mice. When the $\beta$-sitosterol was orally administered $1 \mathrm{~h}$ before histamine injections, the scratching behaviors was reduced (Fig. 5). The inhibition rate of $\beta$-sitosterol ( $2 \mathrm{mg} / \mathrm{kg}$ ) was approximately $39.2 \%(P<0.05)$. 


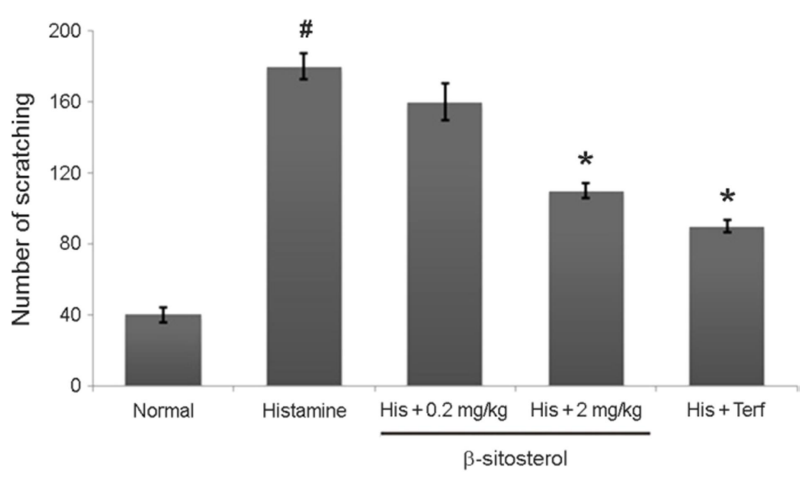

Fig. 5. The effect of $\beta$-sitosterol on scratching behavior in mice. $\beta$-sitosterol $(0.2$ and $2 \mathrm{mg} / \mathrm{kg}$ ) was orally administered $1 \mathrm{~h}$ before histamine $(100 \mu \mathrm{g} / \mathrm{kg})$ intradermal injection. Scratching behavior was counted as one incident of scratching for $30 \mathrm{~min}$. Each datum represents the means \pm S.D. of three independent experiments ( $\# P$ $<0.05$ vs. control group, $* P<0.05$ vs. histamine-treated group).

\section{Effect of $\boldsymbol{\beta}$-sitosterol on IL-6 levels in AD-like skin lesion and HacaT cells}

Inflammatory cytokines are involved in the initiation of the inflammatory response in $\mathrm{AD}$. We investigated the effect of $\beta$-sitosterol on L-6 levels in the AD-like skin lesion. At the end of experiment, the skin tissues were homogenized and ELISA was performed. The levels of IL-6 were significantly increased in the skin tissues of DNCB-treated mice compared to that of control. However, administration of $\beta$-sitosterol reduced these inductions induced by DNCB. The inhibition rate of IL-6 levels by $\beta$-sitosterol $(2 \mathrm{mg} / \mathrm{kg})$ was approximately $25.7 \%$ (Fig. 6A).

The regulatory effect of $\beta$-sitosterol on IL- 6 production in $\mathrm{HaCaT}$ cells was also evaluated. Cells were treated with various concentrations of $\beta$-sitosterol $(0.2,1,2 \mu \mathrm{g} / \mathrm{ml})$ prior to TNF- $\alpha$ plus IFN- $\gamma$-stimulation. As shown in Fig. $6 \mathrm{~B}$, IL-6 production was increased by stimulation with TNF- $\alpha$ plus IFN- $\gamma$ and these increases were inhibited concentrationdependently by $\beta$-sitosterol treatment. The maximal inhibition rate of IL- 6 by $\beta$-sitosterol ( $2 \mathrm{mg} / \mathrm{kg}$ ) was approximately $43.7 \%(P<0.05)$.

\section{DISCUSSION}

Generally, steroid therapy has been used for the treatment of $\mathrm{AD}$ because of their great anti-inflammatory and anti-
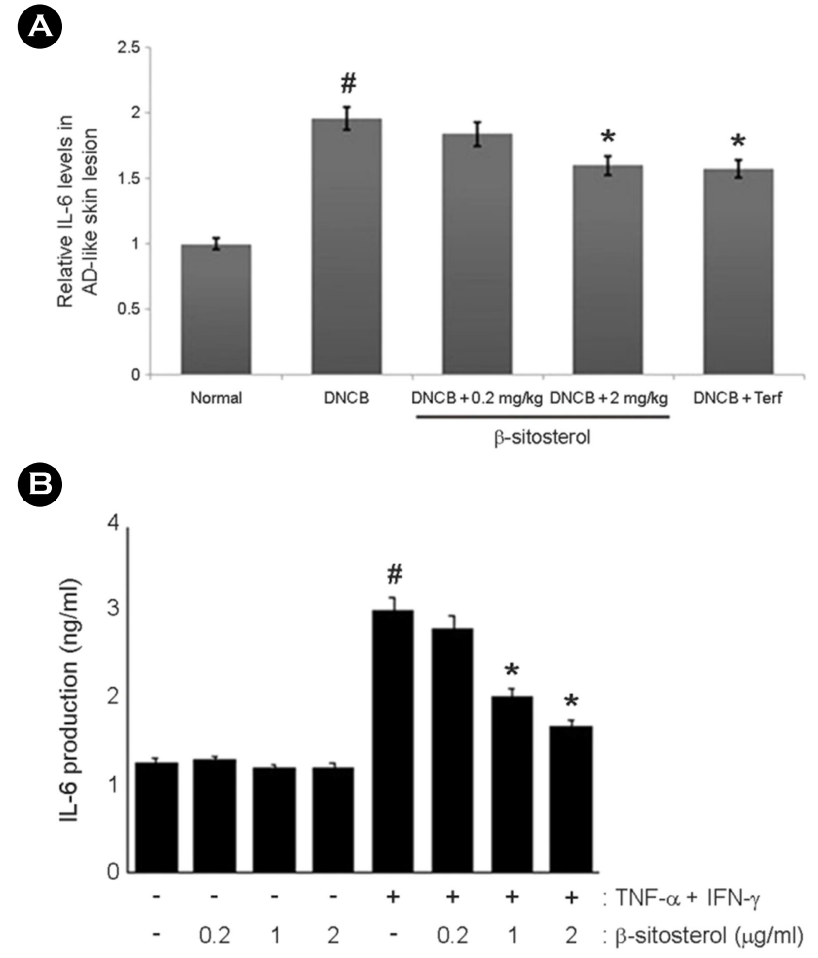

Fig. 6. The effect of $\beta$-sitosterol on the IL-6 levels in AD-like skin tissue and $\mathrm{HaCaT}$ cells (A) At the end of experiment, the skin tissues were cut out and homogenized. The level of IL-6 in the indicated groups was measured via ELISA. (B) Cells were pre-treated with $\beta$-sitosterol $(0.2 \sim 2 \mu \mathrm{g} / \mathrm{ml})$ and then stimulated with TNF- $\alpha$ (10 ng/ $\mathrm{ml})+\mathrm{IFN}-\gamma(10 \mathrm{ng} / \mathrm{ml})$ for $24 \mathrm{~h}$. The IL-6 level in cell supernatants was measured using ELISA. All data were represented in the mean \pm S.D. of triplicate determinations from triplicate separate experiments ( $\# P<0.05$ vs. control, ${ }^{*} P<0.05$ vs. DNCB-treated group, $* * P<0.05$ vs. TNF- $\alpha+$ IFN- $\gamma$ alone).

allergic activities. However, it cannot be administered over the long-term, owing to its deleterious side-effects (Das and Panda, 2017). Therefore, natural product has been the subject of increased interest for its potential in the treatment of $\mathrm{AD}$ (Shiohara et al., 2004). $\beta$-sitosterol is a compound discovered to be present in numerous plants and various biomedical properties including immuno-modulating and anti-inflammatory activities have been reported (Heitzman et al., 2005; Ling and Jones, 1995). In the present report, we demonstrated that anti-atopic effects of $\beta$-sitosterol in AD mice model.

$\mathrm{AD}$ is a common chronic inflammatory skin disease inducing intense itching, edema, erythema, thickening, severe pruritus, and eczematous lesions of the skin (Leung and Bieber, 2003). It was reported that genetic, environmental 
factors and immune responses are associated for the pathogenesis and progression of $\mathrm{AD}$ (Bieber, 2008). IgE dysregulation is implicated with the pathogenesis of $\mathrm{AD}$ and it was reported that serum IgE concentration is generally elevated in patients with AD (Allam and Novak, 2006; Brenninkmeijer et al., 2008). In this study, the result showed that $\beta$-sitosterol significantly reduced the $\mathrm{AD}$ symptoms such as eczematous, erythema and dryness. Additionally, we observed that IgE level in the DNCB group was significantly higher than that in mice in the control group and administration of $\beta$-sitosterol suppressed the increased IgE levels in serum. In pathological skin conditions, histamine is involved in the induction of itching and edema (Minami and Kamei, 2004). This study focused on the manner in which $\beta$-sitosterol regulates the scratching behaviors in mice. We showed that $\beta$-sitosterol inhibited the histamine-induced scratching behaviors in mice and attenuated the DNCB-induced histamine levels in serum. From this, $\beta$-sitosterol possibly may have a therapeutic effect that could alleviate the clinical symptoms associated with AD.

Accumulated experimental evidence shows that IL-6 is implicated with the development of AD. It was also reported that the level of IL-6 is elevated in AD patients and that it plays an integral role in their pathogenesis (Fedenko et al., 2011; Wong et al., 2001). Hence, research on new biological therapies for $\mathrm{AD}$ has focused on blocking components of the inflammatory cytokines. The current study confirmed that the levels of IL-6 increased in AD-like skin lesion compared with those of the control and that treatment with $\beta$-sitosterol reduced these levels. Additionally, $\beta$-sitosterol suppressed the IL- 6 production in TNF- $\alpha$ plus IFN- $\gamma$-stimulated $\mathrm{HaCaT}$ cell. These results indicated that the anti-atopic effect of $\beta$-sitosterol is attributable to the regulation of inflammatory mediator. Although $\beta$-sitosterol attenuated the inflammatory cytokine, the $\beta$-sitosterol's mechanism involved in inflammatory response as not determined in present study. Therefore, further studies will be necessary in order to clarify more precisely the mechanism of $\beta$-sitosterol in AD.

In conclusion, $\beta$-sitosterol can regulate the $\mathrm{AD}$ response in vivo, including DNCB-induced atopic dermatitis and histamine-induced scratching behaviors in mice. Additionally, we demonstrated in this study that the anti-inflammatory activities of $\beta$-sitosterol could be attributed, at least in part, to the inhibition of inflammatory cytokine in $\mathrm{AD}$-like skin lesion and $\mathrm{HaCaT}$ cell. Our current study may provide a basis for the therapeutic use of $\beta$-sitosterol in inflammatory skin diseases such as AD.

\section{ACKNOWLEDGEMENTS}

This research was supported by Basic Science Research Program through the National Research Foundation of Korea (NRF) funded by the Ministry of Education, Science and Technology (2016-0022703) and funded by the Ministry of Education (NRF -2017R1D1A1B03031186).

\section{CONFLICT OF INTEREST}

The authors have no conflicts of interest to disclose.

\section{REFERENCES}

Allam JP, Novak N. The pathophysiology of atopic eczema. Clinical and Experimental Dermatology. 2006. 31: 89-93.

Bieber T. Atopic dermatitis. New England Journal of Medicine. 2008. 358: 1483-1494.

Berke R, Singh A, Guralnick M. Atopic dermatitis: an overview. American Family Physician. 2012. 86: 35-42.

Brenninkmeijer EE, Spuls PI, Legierse CM, Lindeboom R, Smitt $\mathrm{JH}$, Bos JD. Clinical differences between atopic and atopiform dermatitis. Journal of the American Academy of Dermatology. 2008. 58: 407-414.

Buske-Kirschbaum A, Geiben A, Hellhammer D. Psychobiological aspects of atopic dermatitis: an overview. Psychotherapy and Psychosomatics. 2001. 70: 6-16.

Das A, Panda S. Use of Topical Corticosteroids in Dermatology: An Evidence-based Approach. Indian Journal of Dermatology. 2017. 62: 237-250.

Eichenfield LF, Ellis CN, Mancini AJ, Paller AS, Simpson EL. Atopic dermatitis: epidemiology and pathogenesis update Seminars in Cutaneous Medicine and Surgery. 2012. 31: 3-5.

Fedenko ES, Elisyutina OG, Filimonova TM, Boldyreva MN, Burmenskaya OV, Rebrova OY, Yarilin AA, Khaitov RM. Cytokine gene expression in the skin and peripheral blood of atopic dermatitis patients and healthy individuals. Self Nonself. 2011. 2: 120-124.

Gold MS, Kemp AS. Atopic disease in childhood. The Medical 
Journal of Australia. 2005. 182: 298-304.

Hanifin JM, Thurston M, Omoto M, Cherill R, Tofte SJ, Graeber

M. The eczema area and severity index (EASI): assessment of reliability in atopic dermatitis. EASI Evaluator Group. Experimental Dermatology. 2001. 10: 11-18.

Heitzman ME, Neto CC, Winiarz E, Vaisberg AJ, Hammond GB.

Ethnobotany, phytochemistry and pharmacology of uncaria (Rubiaceae). Phytochemistry. 2005. 66: 5-29.

Homey B, Steinhoff M, Ruzicka T, Leung DY. Cytokines and chemokines orchestrate atopic skin inflammation. Journal of Allergy and Clinical Immunology. 2006. 118: 178-189.

Kim SJ, Kim MC, Um JY, Hong SH. The beneficial effect of vanillic acid on ulcerative colitis. Molecules. 2010. 15: 7208-7217.

Leung DY, Bieber T. Atopic dermatitis. Lancet. 2003. 361: 151-160.

Ling WH, Jones PJ. Dietary phytosterols: a review of metabolism, benefits and side effects. Life Science. 1995. 57: 195-206.

Minami K, Kamei CA. Chronic model for evaluating the itching associated with allergic conjunctivitis in rats. International Immunopharmacology. 2004. 4: 101-108.

Saeki H, Furue M, Furukawa F, Hide M, Ohtsuki M, Katayama I, Sasaki R, Suto H, Takehara K. Guidelines for management of atopic dermatitis. The Journal of Dermatology. 2009. 36: 563 -577 .

Shiohara T, Hayakawa J, Mizukawa Y. Animal models for atopic dermatitis: are they relevant to human disease? Journal of Dermatological Science. 2004. 36: 1-9.
Sugimoto M, Arai I, Futaki N, Hashimoto Y, Sakurai T, Honma Y, Nakaike S. Time course changes of scratching counts, dermatitis symptoms, and levels of cutaneous prostaglandins in NC/NGA mice. Experimental Dermatology. 2006. 15: 875 -882 .

Vestergaard C, Bang K, Gesser B, Yoneyama H, Matsushima K, Larsen CG. A Th2 chemokine, TARC, produced by keratinocytes may recruit CLA+CCR4+lymphocytes into lesional atopic dermatitis skin. Journal of Investigative Dermatology. 2000. 115: 640-646.

Wong CK, Ho CY, Ko FW, Chan CH, Ho AS, Hui DS, Lam CW. Proinflammatory cytokines (IL-17, IL-6, IL-18 and IL-12) and Th cytokines (IFN-gamma, IL-4, IL-10 and IL-13) in patients with allergic asthma. Clinical \& Experimental Immunology. 2001. 125: 177-183.

Yoon HJ, Jang MS, Kim HW, Song DU, Nam KI, Bae CS, Kim SJ, Lee SR, Ku CS, Jang DI, Ahn BW. Protective effect of diet supplemented with rice prolamin extract against DNCBinduced atopic dermatitis in BALB/c mice. BMC Complementary and Alternative Medicine. 2015. 15: 353.

https://doi.org/10.15616/BSL.2017.23.4.303

Cite this article as: SJ Kim. The Ameliorative Effect of $\beta$-sitosterol on DNCB-induced Atopic Dermatitis in Mice. Biomedical Science Letters. 2017. 23: 303-309. 